\title{
Bank Ownership and Efficiency in the New EU Members
}

\author{
Jordi Moreno ${ }^{1}$, José Luis Gallizo ${ }^{1}$, Manuel Salvador ${ }^{2}$ \\ ${ }^{1}$ AEGERN Department, University of Lleida, Lleida, Spain \\ ${ }^{2}$ Department of Statistical Methods, University of Zaragoza, Zaragoza, Spain \\ Email: jmoreno@aegern.udl.cat
}

Received October 19, 2011; revised November 22, 2011; accepted December 26, 2011

\begin{abstract}
The aim of this study is to analyze how banking ownership affects banking efficiency in countries which have recently experienced the European integration process more intensely. Using a Bayesian Stochastic Frontier Approach (SFA) applied to panel data, we have estimated efficiency levels in a sample of 226 banks from 12 countries during the period 2000 to 2008. The results show no significant differences between different types of private ownership, questioning the relevance of ownership as a determinant of banking efficiency in these countries. In addition, we have not found any evidence to suggest that foreign ownership is more efficient than its domestic counterpart. These results contradict the popular belief about the higher efficiency levels associated with foreign ownership.
\end{abstract}

Keywords: Bank Ownership; Bank Efficiency; New EU Members; SFA

\section{Introduction}

Banking sectors in Eastern and Central European countries have undergone major transformations over the past two decades, firstly, as a consequence of the transition from centrally planned economy to market economy and, secondly, due to the European integration process. These processes led to the establishment of specific regulations for banks and other financial intermediaries which allowed their modernization and rapid changes in their ownership structures. At first, capital flows were characterized by privatizations and mergers and, subsequently, by the entry of foreign ownership into the industry.

Some studies [1-3] have found evidence of clear improvements in the banking performance of transition economies since the adoption of the new regulations and, especially, since the massive entry of foreign ownership. However, when the studies focus on how changes in bank ownership structure affect the performance of individual banks in these countries, the results are not so clear. While some of them $[1,3,4]$ found that foreignowned banks are more efficient than their domestic counterparts, other studies $[5,6]$ found no evidence of this. It should be noted that most of the studies cited focus on the transition period (1990s) and the years immediately preceding the 2004 enlargement, while only a few studies have worked with more recent data including the years immediately following their accession.

In this article, we analyze the banking efficiency levels estimated for each group of private ownership (we have excluded public ownership because the empirical evidence has reached a certain consensus on its lower levels of efficiency compared to private ownership; [1,7]). We also analyze the impact on banking efficiency levels of incorporating a strategic foreign owner into the ownership structure. In this way, we hope to provide empirical evidence about whether, as popular belief would have it, foreign banks are more efficient than their domestic counterparts or whether, as a consequence of the European integration process, these differences have gradually disappeared.

\section{Data}

Balance sheet and income data are taken from the Bureau Van Dijk's BankScope data base. Specifically, we have chosen all currently active private commercial banks in the 12 countries that have experienced the European integration process more intensely in recent years and for which there are data available for all necessary variables for the estimation of efficiency levels for at least one year between 2000 and 2008. This period was chosen because of the intensification of the European integration process experienced by central and eastern European countries during these years. In total, the dataset consists of 226 banks.

In Table 1, we can see the composition of the sample by ownership types and by countries; it also shows the presence of strategic owners in the sample. Banks are divided into three mutually exclusive and collectively exhaustive private ownership types, namely, foreign Greenfield banks, new domestic private banks and privatized banks. 
Table 1. Distribution of banks across bank types by country.

\begin{tabular}{cccccc}
\hline \multirow{2}{*}{ Country } & \multicolumn{5}{c}{ Ownership } \\
\cline { 2 - 6 } & $\begin{array}{c}\text { New domestic } \\
\text { private }\end{array}$ & $\begin{array}{c}\text { Foreign } \\
\text { Greenfield }\end{array}$ & Privatized & $\begin{array}{c}\text { Strategic } \\
\text { owner }\end{array}$ & Total \\
\hline Bulgaria & 9 & 6 & 3 & 8 & 18 \\
Croatia & 20 & 4 & 4 & 11 & 28 \\
Czech & 5 & 7 & 5 & 9 & 17 \\
Republic & 6 & 0 & 1 & 5 & 7 \\
Estonia & 4 & 10 & 8 & 8 & 22 \\
Hungary & 14 & 1 & 5 & 11 & 20 \\
Latvia & 14 & 1 & 4 & 5 & 10 \\
Lithuania & 5 & 0 & 6 & 6 & 11 \\
Macedonia & 5 & 18 & 8 & 18 & 42 \\
Poland & 16 & 9 & 3 & 12 & 22 \\
Romania & 10 & 4 & 6 & 9 & 14 \\
Slovakia & 4 & 1 & 9 & 4 & 15 \\
Slovenia & 5 & 61 & 62 & 106 & 226 \\
Total & 103 & & & &
\end{tabular}

\section{Methodology}

In order to estimate the cost and profit efficiency of a bank, we have used stochastic frontier models. We have opted for the added value approach [8] and following [1] we have used three outputs: deposits (D), loans (L) and other earnings assets (G), and two input prices: capital price (CP), measured by the ratio of total operating expenses over fixed assets, and fund price (FP), measured by the ratio of financial expenses over total deposits.. Our dependent variables are total cost (C) for cost efficiency and profits before taxes (B) for profit efficiency.

We have used a translog specification for the model with fixed effects for each country and year. So, if "i" denotes the bank and "t" the period, the equation of the model is given by:

$$
\begin{aligned}
y_{\mathrm{it}}= & \alpha+\beta_{1} \mathrm{~d}_{\mathrm{it}}+\beta_{2} \ell_{\mathrm{it}}+\beta_{3} \mathrm{~g}_{\mathrm{it}}+\beta_{4} \mathrm{pc}_{\mathrm{it}}+\beta_{5} \mathrm{pf}_{\mathrm{it}}+\beta_{6} \mathrm{~d}_{\mathrm{it}}^{2} \\
& +\beta_{7} \mathrm{~d}_{\mathrm{it}} \ell_{\mathrm{it}}+\beta_{8} \mathrm{~d}_{\mathrm{it}} \mathrm{g}_{\mathrm{it}}+\beta_{9} \mathrm{~d}_{\mathrm{it}} \mathrm{pc}_{\mathrm{it}}+\beta_{10} \mathrm{~d}_{\mathrm{it}} \mathrm{pf}_{\mathrm{it}}+\beta_{11} \ell_{\mathrm{it}}^{2} \\
& +\beta_{12} \ell_{\mathrm{it}} \mathrm{g}_{\mathrm{it}}+\beta_{13} \ell_{\mathrm{it}} \mathrm{pc}_{\mathrm{it}}+\beta_{14} \ell_{\mathrm{it}} \mathrm{pf}_{\mathrm{it}}+\beta_{15} \mathrm{~g}_{\mathrm{it}}^{2}+\beta_{16} \mathrm{~g}_{\mathrm{it}} \mathrm{pc}_{\mathrm{it}} \\
& +\beta_{17} \mathrm{~g}_{\mathrm{it}} \mathrm{pf}_{\mathrm{it}}+\beta_{18} \mathrm{pc}_{\mathrm{it}}^{2}+\beta_{19} \mathrm{pc}_{\mathrm{it}} \mathrm{pf}_{\mathrm{it}}+\beta_{20} \mathrm{pf}_{\mathrm{it}}^{2} \\
& +\sum_{\mathrm{j}=2}^{12} \beta_{20+\mathrm{j}-1} \mathrm{IP}_{\mathrm{ij}}+\sum_{\mathrm{j}=2}^{9} \beta_{31+\mathrm{j}-1} \mathrm{IT}_{\mathrm{ij}}+\mathrm{u}_{\mathrm{it}}+\varepsilon_{\mathrm{it}}
\end{aligned}
$$

$$
\begin{aligned}
\text { if } y_{\mathrm{it}}= & \log \left(\mathrm{C}_{\mathrm{it}}\right) \text { and } \\
y_{\mathrm{it}}=\alpha & +\beta_{1} \mathrm{~d}_{\mathrm{it}}+\beta_{2} \ell_{\mathrm{it}}+\beta_{3} \mathrm{~g}_{\mathrm{it}}+\beta_{4} \mathrm{pc}_{\mathrm{it}}+\beta_{5} \mathrm{pf}_{\mathrm{it}}+\beta_{6} \mathrm{~d}_{\mathrm{it}}^{2} \\
& +\beta_{7} \mathrm{~d}_{\mathrm{it}} \ell_{\mathrm{it}}+\beta_{8} \mathrm{~d}_{\mathrm{it}} \mathrm{g}_{\mathrm{it}}+\beta_{9} \mathrm{~d}_{\mathrm{it}} \mathrm{pc}_{\mathrm{it}}+\beta_{10} \mathrm{~d}_{\mathrm{it}} \mathrm{pf}_{\mathrm{it}}+\beta_{11} \ell_{\mathrm{it}}^{2} \\
& +\beta_{12} \ell_{\mathrm{it}} \mathrm{g}_{\mathrm{it}}+\beta_{13} \ell_{\mathrm{it}} \mathrm{pc}_{\mathrm{it}}+\beta_{14} \ell_{\mathrm{it}} \mathrm{pf}_{\mathrm{it}}+\beta_{15} \mathrm{~g}_{\mathrm{it}}^{2}+\beta_{16} \mathrm{~g}_{\mathrm{it}} \mathrm{pc}_{\mathrm{it}} \\
& +\beta_{17} \mathrm{~g}_{\mathrm{it}} \mathrm{pf}_{\mathrm{it}}+\beta_{18} \mathrm{pc}_{\mathrm{it}}^{2}+\beta_{19} \mathrm{pc}_{\mathrm{it}} \mathrm{pf}_{\mathrm{it}}+\beta_{20} \mathrm{pf}_{\mathrm{it}}^{2} \\
& +\sum_{\mathrm{j}=2}^{12} \beta_{20+\mathrm{j}-1} \mathrm{IP}_{\mathrm{ij}}+\sum_{\mathrm{j}=2}^{9} \beta_{31+\mathrm{j}-1} \mathrm{TT}_{\mathrm{ij}}-\mathrm{u}_{\mathrm{it}}+\varepsilon_{\mathrm{it}}
\end{aligned}
$$

if $y_{\mathrm{it}}=\log \left(\mathrm{B}_{\mathrm{it}}\right)$, where $\mathrm{d}_{\mathrm{it}}=\log \left(\mathrm{D}_{\mathrm{it}}\right) ; \ell_{\mathrm{it}}=\log \left(\mathrm{L}_{\mathrm{it}}\right) ; \mathrm{g}_{\mathrm{it}}=$ $\log \left(\mathrm{G}_{\mathrm{it}}\right)$; $\mathrm{pc_{it }}=\log \left(\mathrm{PC}_{\mathrm{it}}\right) ; \mathrm{pf}_{\mathrm{it}}=\log \left(\mathrm{PF}_{\mathrm{it}}\right)$; $\mathrm{IP}_{\mathrm{ij}}$ and $\mathrm{IT}_{\mathrm{ij}}$ are indicators of the $\mathrm{j}$-th country and the $\mathrm{j}$-th period, respectively; $\mathrm{u}_{\mathrm{it}}$ is the inefficiency term; $\varepsilon_{\mathrm{it}} \sim \mathrm{N}\left(0, \sigma^{2}\right)$ is the error and $t \in T_{i}, T_{i} \subseteq\{1, \cdots, T\} ; i=1, \cdots, N$ where $T_{i}$ is the observation period of the i-th bank and $\mathrm{N}$ is the number of analyzed banks.

We have assumed that $u_{\mathrm{it}} \sim \mathrm{NT}_{(0, \infty)},\left(\gamma \mathrm{w}_{\mathrm{it}}, \sigma_{\mathrm{u}}^{2}\right)$, where $\mathrm{w}_{\mathrm{it}}=\left(\mathrm{w}_{\mathrm{it} 1}, \cdots, \mathrm{w}_{\mathrm{itk}}\right)$ are the explanatory characteristics of bank inefficiency and $\gamma=\left(\gamma_{1}, \cdots, \gamma_{k}\right)^{\prime}$ a vector of parameters that quantifies their influence on the efficiency level $\mathrm{r}_{\mathrm{it}}=\mathrm{e}^{-\mathrm{u}_{\mathrm{it}}}$.

In order to estimate the parameters of the model we have used the Bayesian approach described in [9] that allows us to make exact inferences about them.

\section{Results}

Table 2 and Figures 1 and 2 show the estimated mean cost and profit efficiency levels for the three types of ownership mentioned above. They are very similar for both cost and profit efficiency, the most outstanding result being the complete lack of significant differences between them. This result suggests that, nowadays, ownership type is no longer a determinant of banking efficiency in these countries.

Table 3 shows the estimated mean cost and profit efficiency levels for the banks before and after the incorporation of a strategic foreign owner. A very small increase in cost efficiency can be appreciated after the incorporation of a strategic foreign owner. In contrast, profit efficiency is basically unaltered after this incorporation. In both cases we note, however, that the most outstanding result is the complete lack of significant differences between the efficiency levels estimates for banks before

Table 2. Cost and profit efficiency estimates by three types of ownership.

\begin{tabular}{lcccccc}
\hline & & Cost efficiency & & \multicolumn{2}{c}{ Profit efficiency } \\
\hline & C2.5 & Median & C97.5 & C2.5 & Median & C97.5 \\
\hline E[rt| new domestic private bank] & 0.3675 & 0.4561 & 0.5389 & 0.6319 & 0.6884 & 0.7376 \\
E[rt| foreign Greenfield bank] & 0.3859 & 0.4902 & 0.5901 & 0.6248 & 0.6915 & 0.7585 \\
E[rt| privatized bank] & 0.3563 & 0.4505 & 0.5410 & 0.6120 & 0.6688 & 0.7186 \\
\hline
\end{tabular}




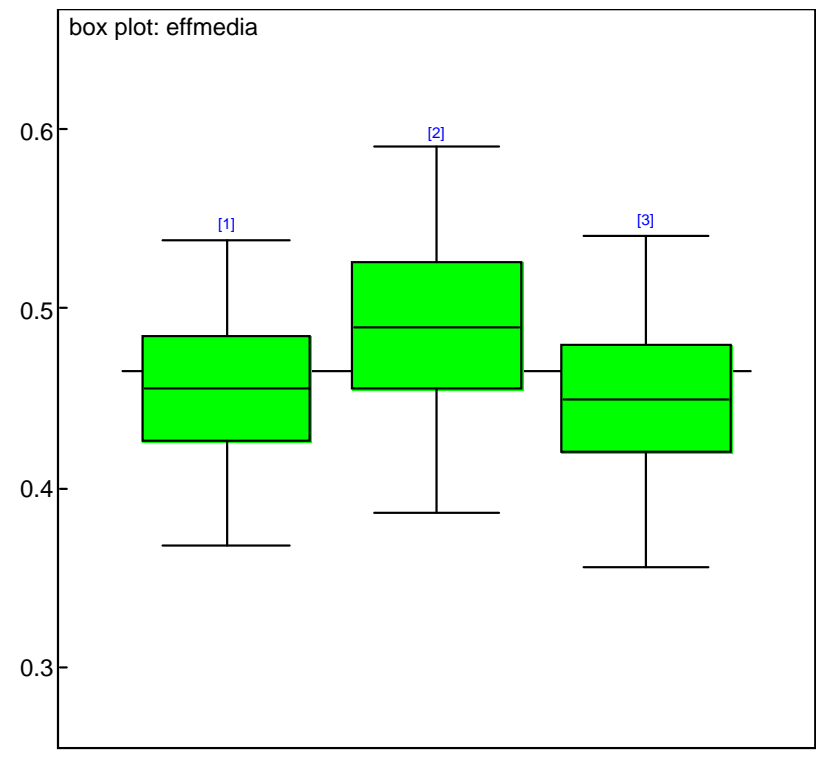

Figure 1. Boxplot of cost efficiency estimates by 3 types of ownership.

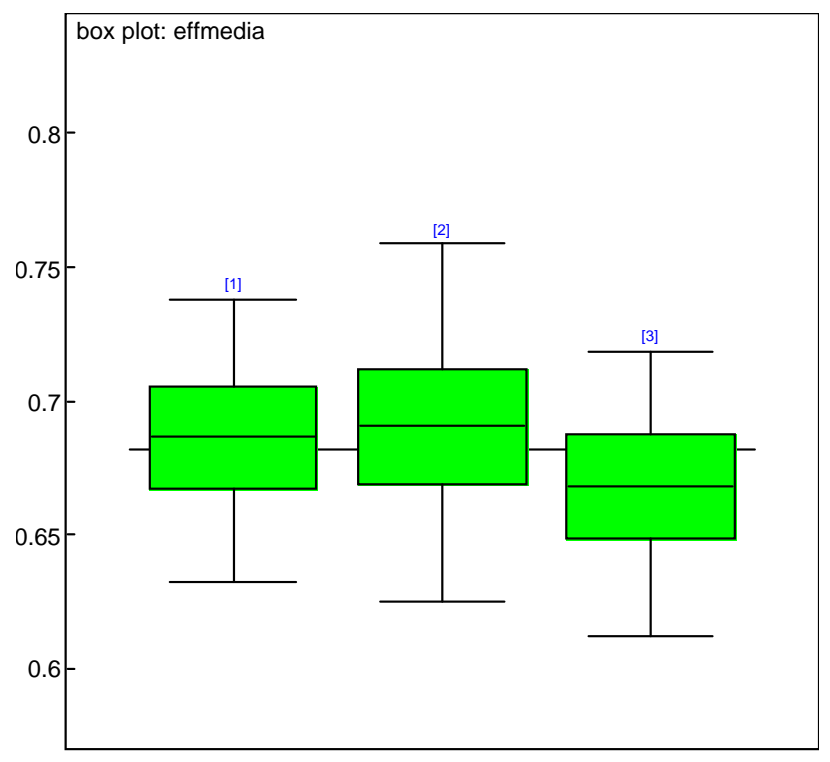

Figure 2. Boxplot of profit efficiency estimate by 3 types of ownership.

Table 3. Effect of incorporating a strategic foreign owner on banking efficiency.

\begin{tabular}{lccccccc}
\hline & & Cost efficiency & & \multicolumn{3}{c}{ Profit efficiency } \\
\hline & $\mathbf{C 2 . 5}$ & Median & $\mathbf{C 9 7 . 5}$ & C2.5 & Median & C97.5 \\
\hline $\mathbf{E}\left[\mathbf{r}_{\mathbf{t}} \mid \mathbf{t}<\right.$ strategic owner incorporation] & 0.3811 & 0.4653 & 0.5415 & 0.6411 & 0.6864 & 0.7301 \\
$\mathbf{E}\left[\mathbf{r}_{\mathbf{t}} \mid \mathbf{t} \geq\right.$ strategic owner incorporation] & 0.3826 & 0.4753 & 0.5595 & 0.6393 & 0.6862 & 0.7309 \\
\hline
\end{tabular}

and after the incorporation of a strategic owner.

Tables 4 and 5 show the results of analyzing the combined influence of the type of ownership and the presence/absence of a strategic foreign owner. This analysis has been carried out from both an aggregated and a disaggregated perspective.

In the aggregated analysis, we have grouped the banks into two categories depending on their type of ownership. The first group contains all banks controlled totally or mostly by domestic ownership (new domestic private banks without a strategic foreign owner and privatized banks without a strategic foreign owner), whereas the second group contains all banks controlled totally or mostly by foreign ownership (new domestic private banks with a strategic foreign owner, privatized banks with a strategic foreign owner and foreign Greenfield banks). The estimated efficiency levels for each group are reported in Table 4.

We can see that domestic banks tend to be more cost and profit efficient than foreign banks, although the differences between two groups are not statistically signifycant. As a consequence of this lack of statistical robustness in the results, we can not affirm that domestic banks are more efficient than foreign banks; however, these re- sults provide enough evidence to doubt the higher levels of banking efficiency we traditionally associate with foreign ownership.

In the disaggregated analysis, we have combined the type of ownership and the presence/absence of a strategic foreign owner to estimate the efficiency levels of five ownership types: new domestic private banks without a strategic foreign owner, privatized banks without a strategic foreign owner, new domestic private banks with a strategic foreign owner, privatized banks with a strategic foreign owner and foreign Greenfield banks. The results obtained for each group are reported in Table $\mathbf{5}$ and in Figures 3 and 4.

Differences between the efficiency levels estimated for cost and profit efficiency can be appreciated although, in both cases, the observed differences are not, in general, statistically significant. Regarding cost efficiency, privatized banks without strategic foreign owner tend to be a little bit more efficient, followed by new domestic private banks without a strategic foreign owner. Regarding profit efficiency, new domestic private banks without a strategic foreign owner tend to be a little bit more efficient, followed by privatized banks without a strategic foreign owner. 
Table 4. Banking efficiency levels for domestic and foreign ownership.

\begin{tabular}{lcccccc}
\hline & & Cost efficiency & \multicolumn{3}{c}{ Profit efficiency } \\
\hline & C2.5 & Median & C97.5 & C2.5 & Median & C97.5 \\
\hline $\mathbf{E}\left[\mathbf{r}_{\mathbf{t}} \mid\right.$ domestic ownership in $\left.\mathbf{t}\right]$ & 0.3641 & 0.4897 & 0.5876 & 0.6418 & 0.6990 & 0.7429 \\
$\mathbf{E}\left[\mathbf{r}_{\mathbf{t}} \mid\right.$ foreign ownership in $\left.\mathbf{t}\right]$ & 0.3211 & 0.4305 & 0.5208 & 0.6026 & 0.6579 & 0.7032 \\
\hline
\end{tabular}

Table 5. Cost and profit efficiency estimates by five types of ownership.

\begin{tabular}{|c|c|c|c|c|c|c|}
\hline & \multicolumn{3}{|c|}{ Cost efficiency } & \multicolumn{3}{|c|}{ Profit efficiency } \\
\hline & C2.5 & Median & C97.5 & $\mathrm{C} 2.5$ & Median & C97.5 \\
\hline$E\left[r_{t} \mid\right.$ new domestic private bank without strategic owner] & 0.3698 & 0.4794 & 0.5765 & 0.6445 & 0.6898 & 0.7506 \\
\hline$E\left[r_{t} \mid\right.$ privatized bank without strategic owner $]$ & 0.3693 & 0.5058 & 0.6392 & 0.6183 & 0.6854 & 0.7673 \\
\hline$E\left[r_{t} \mid\right.$ new domestic private bank with strategic owner $]$ & 0.3308 & 0.4320 & 0.5309 & 0.6069 & 0.6493 & 0.7111 \\
\hline $\mathbf{E}\left[\mathbf{r}_{\mathbf{t}} \mid\right.$ privatized bank with strategic owner $]$ & 0.3344 & 0.4512 & 0.5497 & 0.5946 & 0.6445 & 0.7070 \\
\hline$E\left[r_{t} \mid\right.$ foreign Greenfield bank $]$ & 0.3129 & 0.4128 & 0.5002 & 0.6097 & 0.6522 & 0.7145 \\
\hline
\end{tabular}

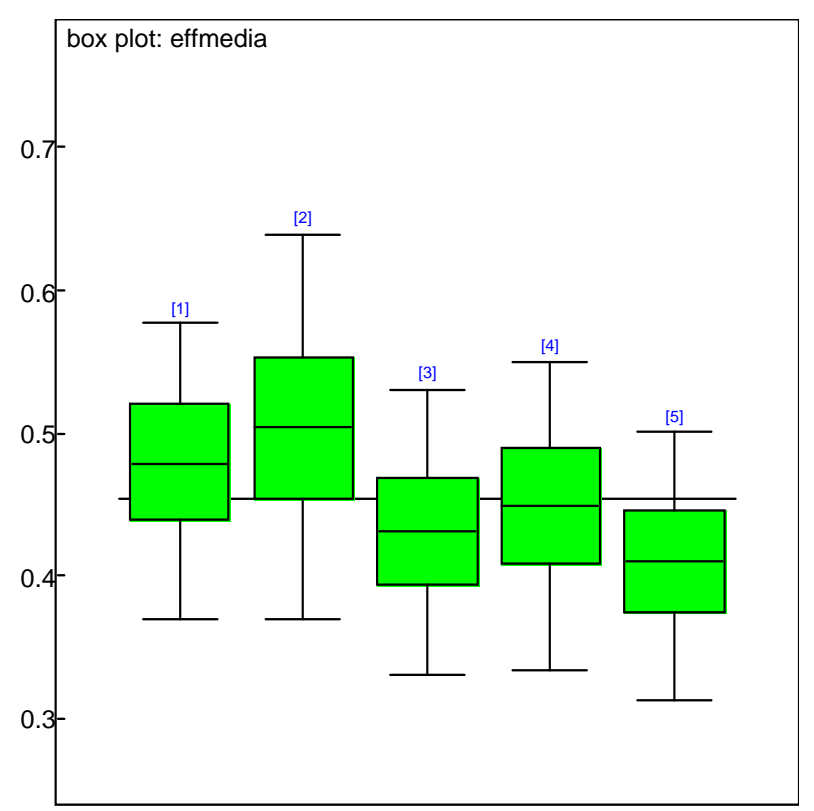

Figure 3. Boxplot of cost efficiency estimates by 5 types of ownership.

\section{Conclusions}

In this paper, we analyze the influence of different private ownership types on banking efficiency in new EU members. We find that, nowadays, the type of private ownership does not exert a significant effect on banking efficiency. In our opinion, this result could be explained by the existence of a convergence process of banking practices as a consequence of the adoption of the same EU Directives in all EU countries.

Furthermore, we find higher efficiency levels in banks controlled totally or mostly by domestic ownership. Even though the differences are not statistically significant, this result casts doubt on the higher levels of banking efficiency that are traditionally associated with foreign ownership. In our opinion, this result could be partly explained by the government policies implemented in these

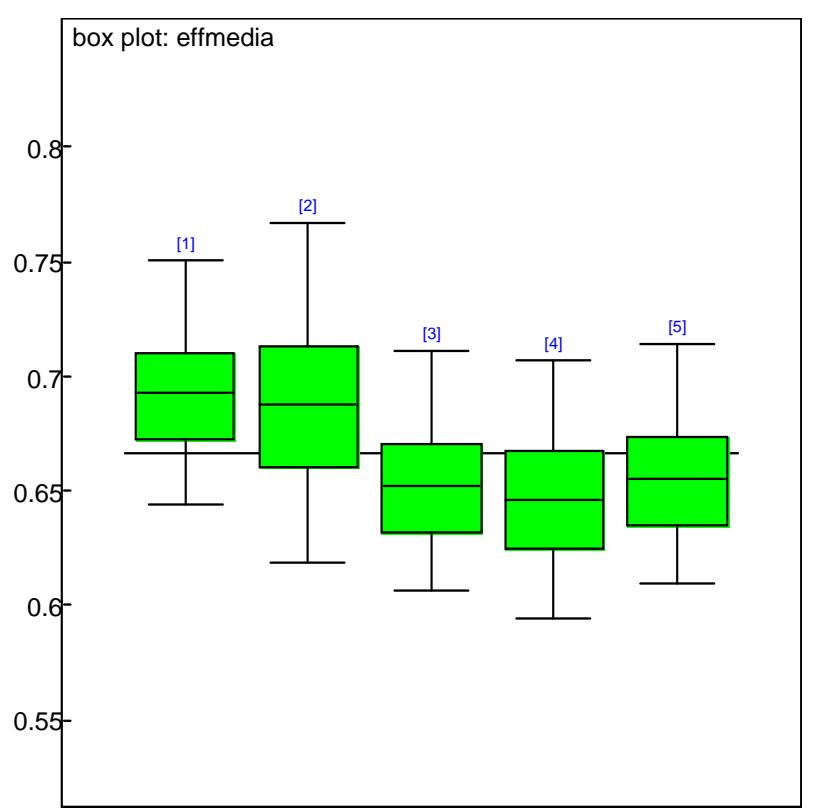

Figure 4. Boxplot of profit efficiency estimates by 5 types of ownership.

countries in the late 1990s, which promoted the entry of foreign owners into banks with liquidity and solvency problems, a legacy that could be a burden for their efficiency levels and, therefore, it could explain the lower efficiency of banks with a strategic foreign owner.

In this study, we analyze cost and profit efficiency levels separately. Since costs and profits are closely related, we think it would be very interesting and more realistic to try to analyze these two variables together, as studies such as [10] have done. This constitutes a future line of research, the results of which will be presented elsewhere.

\section{REFERENCES}

[1] J. P. Bonin, I. Hasan and P. Wachtel, "Privatization Matters: Bank Efficiency in Transition Countries,” Journal of 
Banking and Finance, Vol. 29, No. 8-9, 2005, pp. 21552178. doi:10.1016/j.jbankfin.2005.03.012

[2] S. Claessens, A. Demirgüç-Kunt and H. Huizinga, "How Does Foreign Entry Affect the Domestic Banking Market?” Journal of Banking and Finance, Vol. 25, No. 5, 2001, pp. 891-911. doi:10.1016/S0378-4266(00)00102-3

[3] S. Fries and A. Taci, "Cost Efficiency of Banks in Transition: Evidence from 289 Banks in 15 Post-Communist Countries,” Journal of Banking and Finance, Vol. 29, No. 1, 2005, pp. 55-81. doi:10.1016/j.jbankfin.2004.06.016

[4] O. Havrylchyk, "Efficiency of the Polish Banking Industry: Foreign versus Domestic Banks,” Journal of Banking and Finance, Vol. 30, No. 7, 2006, pp. 1975-1996. doi:10.1016/j.jbankfin.2005.07.009

[5] C.J. Green, V. Murinde and I. Nikolov, "The efficiency of Foreign Banks in Central and Eastern Europe: Evidence on Economies of Scale and Scope,” Journal of Emerging Markets Finance, Vol. 3, No. 2, 2004, pp. 175-205. doi:10.1177/097265270400300205

[6] I. Hasan and K. Marton, "Development and Efficiency of the Banking Sector in a Transitional Economy: Hungarian
Experience,” Journal of Banking and Finance, Vol. 27, No. 12, 2003, pp. 2249-2271. doi:10.1016/S0378-4266(02)00328-X

[7] R. La Porta, F. López-De-Silanes and A. Shleifer, “Government Ownership of Banks," Journal of Finance, American Finance Association, Vol. 57, No. 1, 2002, pp. 265301.

[8] A. N. Berger and D. B. Humphrey, "Efficiency of Financial Institutions: International Survey and Directions for Future Research,” European Journal of Operational Research, Vol. 98, No. 2, 1997, pp. 175-212. doi:10.1016/S0377-2217(96)00342-6

[9] J. E. Griffin and M. F. J. Steel, "Bayesian Stochastic Frontier Analysis Using Winbugs,” Journal of Productivity Analysis, Vol. 27, No. 3, 2007, pp. 163-176. doi:10.1007/s11123-007-0033-y

[10] C. Fernández, G. Koop and M. F. J. Steel, “A Bayesian Analysis of Multiple-Output Production Frontiers," Journal of Econometrics, Vol. 98, No. 1, 2000, pp. 47-79. doi:10.1016/S0304-4076(99)00074-3 